\title{
NOTES AND QUERIES.
}

\section{A Function of the Tonsils.}

Bacteria in the blood are derived from various sources. Eccles, in comnenting on the power of the body cells to resist bacterial invasion, calls attention to the fact that such resistance is a response to the action of bacteria that are early introduced into the blood stream, and that an early introduction of bacteria, such as occurs in some instances through the tonsils, is essential to the development of this defence. If this is true the tonsils and kindred organs may on occasion assume the role of immunisers, permitting just a sufficient number of bac eria to enter the circulation at an early stage of the infection to develop resistance to the specific organism.-W. J. MA yo (Rochester), The Lancet, Norember 25, 1916.

\section{Edingurgh Scheme for Deaf Soldiers.}

Hitherto the cause of the soldier deafened in his country's service has scarcely received the sympathy and public attention which it deserves. In this matter Scotland has given a lead. The Edinburgh Lip-Reading Association, finding that little was being done for the thousand soldiers discharged up to a year ago with damaged powers of hearing, took up the matter and raised funds. The Edinburgh School Board agreed to supply class-rooms and teachers, while the association undertook the care of the men during their period of training. The first session of six weeks' instruction organised by the association lately came to a close, when the class was inspected by the Marquis of Graham. It is to be hoped that this valuable work will be undertaken in other centres without delay, so that the deaf soldier may no longer feel that he is "nobody's child."Brit. Med. Journ., June 16, 1917.

\section{Training of Deap Dischargen Soldiers.}

Sir A. Griffith Boscawen, replying to Mr. Holmes, said:-The Statutory Committee have made thorough inquiries into the best methods of treating and training the deaf, and, with the assistance of the Board of Education in England and of the Education Offices in Scotland and Ireland, are arranging for the establishment of centres of instruction in lip-reading. Very few deaf disabled men have, however, applied for instruction or have accepted it when offered, and it is now proposed to establish a special aural board, who will get into touch with the men at the time of discharge or renewal of pension, with a view to their advising and getting the men to take the treatment or training most suitable for them.-The Times, Tuesday, July 3, 1917.

\section{Medical Society of London.}

We note with satisfaction that our confrère Sir StClair Thomson has been elected President of the Medical Society of London for the Session commencing in October next.

On looking back through the list of presidents since its foundation in 1773 we see that the presidency has never before been awarded to one of our specialists, with the exception of the year 1894, when Sir William Dalby occupied the chair. It also appears to have been once filled by an ophthalmologist, viz. Mr. Brudenell Carter in 1886.

Mr. Charles J. Heath, F.R.C.S., has been appointed Consulting Aurist to the Metropolitan Asylums Board Infirmary for Children, London, W. 1.

\section{BOOK RECEIYED.}

Contribución a la Cirurgià de la Hipofisis. By Dr. E. V. Segura, Buenos Ayres, 1916. 
Dr. Irwin Moore's UNIVERSAL FORCEPS

For Removing Foreign Bodies from the Esophagus, Trachea, or Bronchi. And ENDOSCOPIC CUTTING FORCEPS or SHEARS And

For Cutting through Tooth-plates, Pins, or Bones. Dr. William Hill's EXPANDING GESOPHAGOSCOPE

For assisting in Removal of Impacted Tooth-plates, etc.

See LANCET, May 13 th, 1916.

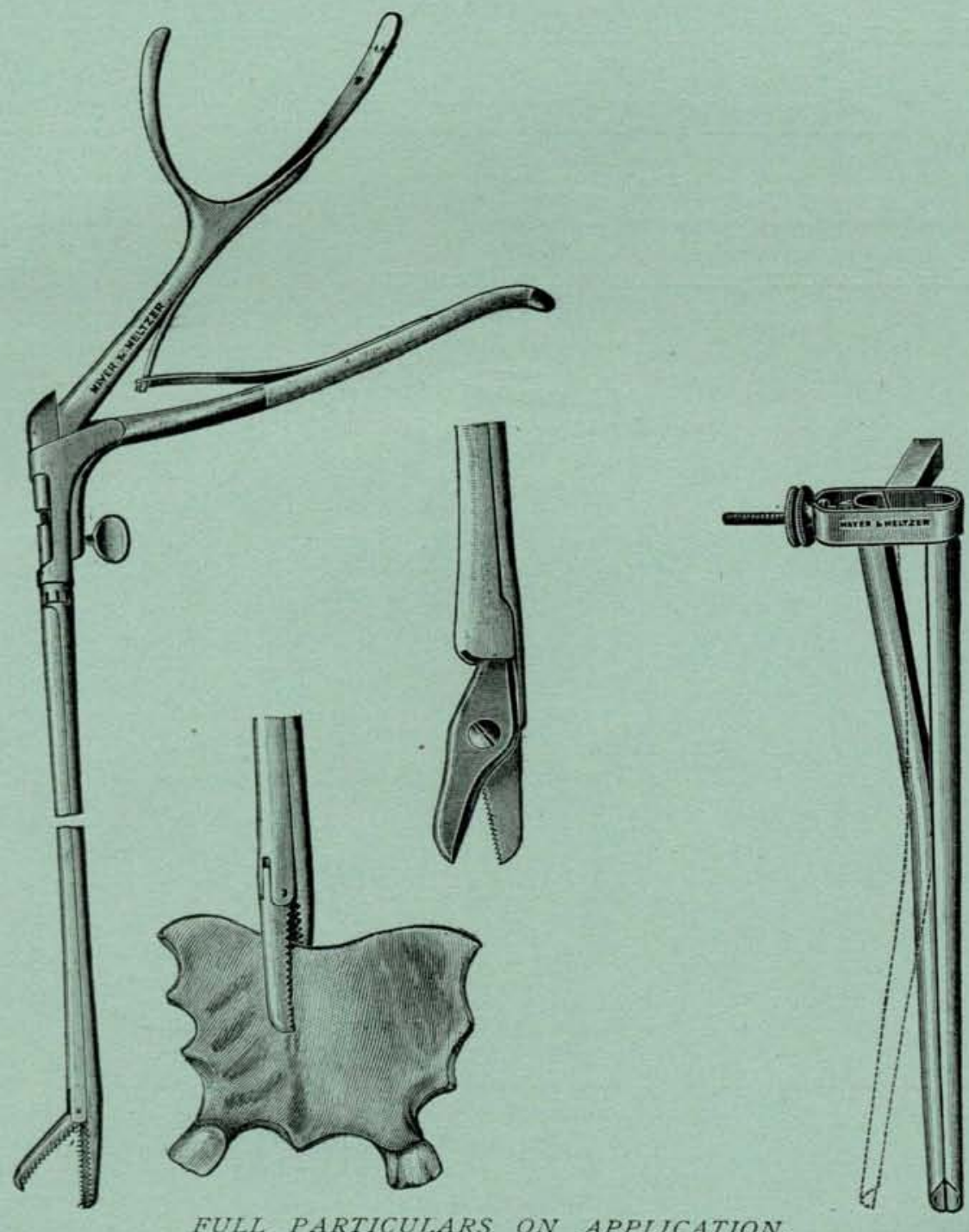

MAYER \& MELTZER, 71, GT. PORTLAND ST., LONDON, W. 


\section{MAYER \& MELTZER,}

Surgical Instrument Makers.

ESTABLISHED OVER FIFTY YEARS.

\section{Regulating Apparatus for the}

\section{Administration of Warm Anasthetic Vapours.}

(Vide article in LANCET, Jan. 8th, 1916, by Francis E. Shipway, M.A., M.D.Cantab.)

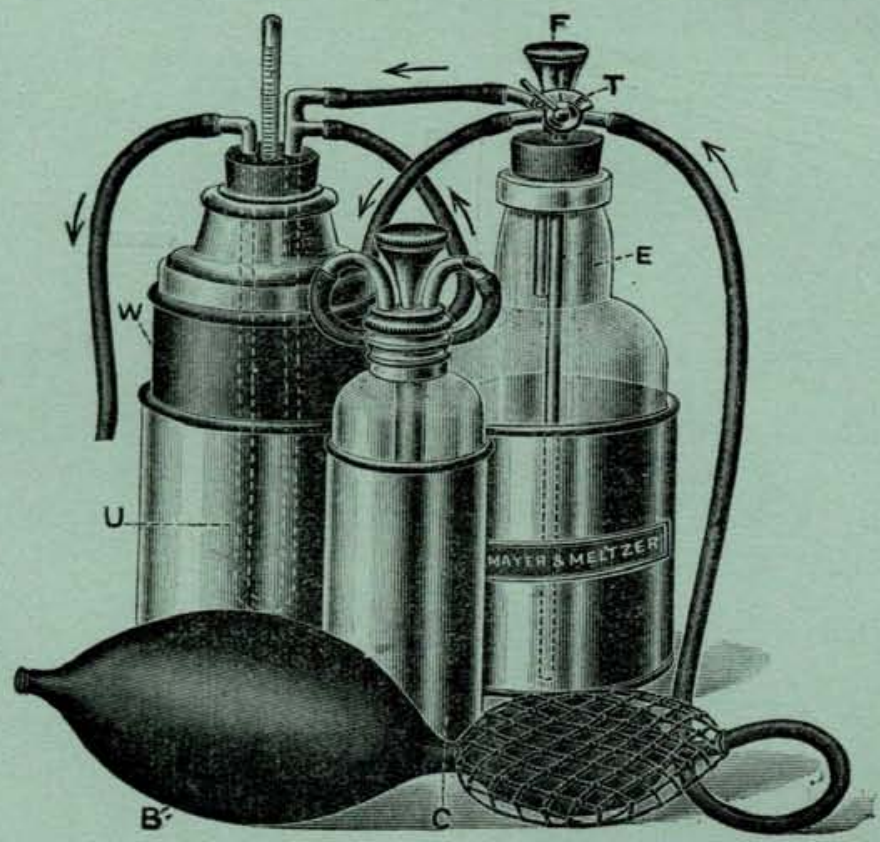

The Administration of Warm Ether Vapour has all the advantages of the Open Ether

Method, and is safer. There is less loss of body heat, less shock, less consumption of the anæsthetic.

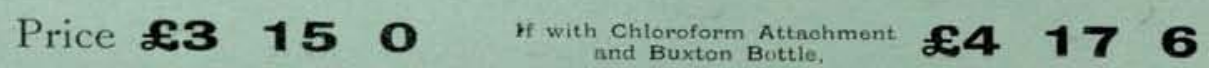

MAYER \& MELTZER, 7I, GREAT PORTLAND ST., LONDON. Contractors to the War Office. 